\title{
Técnicos de Administração
}

$A$ carreira de Técnico de Administração, criada sob tão bons auspícios há menos de vinte anos, ainda hoje é privativa, no Serviço Público Federal, do Ministério da Justiça e do Departamento Administrativo do Serviço Público. Portanto não será exagêro dizer-se: foi uma idéia feliz que parece não ter medrado. Continua tão incompreendida como à época de sua criação, mesmo por aquêles que dela poderiam utilizar-se com maior proveito, a fim de concretizar iniciativas ou programas, em geral malogrados porque desservidos em orǵanização ou pessoal. Um inócuo e dispendioso ornamento - é o que muitas vêzes pensam certas fíguras de responsabilidade, sem manifestar o julgamento com tal crueza, mas revelando com êle essa incapacidade de trabalhar em grupo, que se tornou quase proverbial em nosso homem público.

A despeito de tudo, apressaram-se outros governos e organizações - estaduais e municipais ou autarquias - a incorporá-la ̀̀s respectivas administrações. E se o fizeram é que os Técnicos correspondiam, sem dúvida, a uma necessidade dos serviços públicos em nosso país, cada vez mais diversificados em sua ação e em seus empreendimentos. O crescente grau de interferência do Estado, em ordens que antes the eram estranhas, como que passou a exigir essa contínua assistência do Técnico aos responsáveis pelá exectição ou pela fixação de diretrizes governamentais. E quando não existe tal assistência, ocorrem fatos que seria indelicado recotdar.

Coube a responsabilidade de criação da carreira ao espírito pioneiro e de largo descortino do Sr. LuIz Simões Lopes, que, por volta de 1940, intentava atrair, para o Serviço Público Federal, elementos de escol, com os quais pudesse planejar e levar a cabo a Reforma Administrativa, por êle iniciada, mas ainda hoje interrompida, embora reclamada em todos os quadrantes da opinião culta do país. Daí, a estruturação e o alto nível, que advogou para a 
carreira, junto ao Poder Executivo, na qualidade de primeiro Diretor Geral do D.A.S.P., o que the permitiu dar, logo de inicio, aos concursos para provimento dos cargos de Técnico de Administração, uma repercussão como poucas vêzes se terá observado igual na história do Sistema do Mérito em nosso país. Do acêrto da iniciativa, inspirada em tão sincero desejo de bem servir, falam bem alto os valores que atenderam a êsse apêlo do são idealismo que norteava o Sr. Luiz Simões Lopes. Com efeito, os primeiros concursos que se realizaram - 1940 a 1943 - conseguiram interessat a homens da envergadura mental e da probidade moral de CARios Alberto Lucio Bittencourt, Ary de CAstro FerNANDES e ARLINDO RAMOS - para mencionar apenas os que já se foram - sem que precisemos fazer referência - neste local inteiramente descabida - aos que ainda estão vivos e a prestar, em diferentes setores, os melhores serviços à vida pública do país.

Registre-se que agora vai essa carreira passar por uma de suas periódicas renovações, por isto que terá lugar, pròximamente, novo concurso para provimento de seus cargos iniciais. Há mais de duzentas inscrições e tudo leva a crer, à primeira vista, que os resultados sejam promissores. Mas não há a menor semelhança entre a situação de hoje e a de 15 anos atrás: retrogradamos sensivelmente. Nem alimentam esperanças de uma brilhante seleção os que têm conhecimento assás intimo das condições de funcionamento da administração federal. Pois a verdade já não pode mais ser obscurecida: o Técnico de Administração deveras capaz tem, presentemente, na indústria ou no comércio, maiores e melhores oportunidades do que no govêrno federal - isto é, melhor remuneração e maior compreensão do valor de seu trabalho, o que equivale a dizer: tem incentivos. Não é provável, assim, que as inscrições prenunciem o comparecimento efetivo à primeira prova, nem tampouco se espera sejam de nível técnico satisfatório os que a ela se subnieterão.

Observou há meses um perspicaz sociólogo norte-americano - o Sr. LynN SMith - conhecedor e amigo profundo de nossas coisas e de nossa gente, - que não haverá país no mundo onde a produção - sobretudo a agrícola - resulte de maior soma de esforços e de mais absurdo desperdício de energias. Constitui, na verdade, lugar comum economico incluir entre as causas paralizantes de nosso desenvolvimento, ou entre as que podem explicar tan- 
tos fracassos inesperados, em qualquer empreendimento ou serviço, a deficiência do Know-how, isto é, da técnica, muitas vêzes a mais comezinha. Não é realmente novidade que carecemos de capitais; todavia nunca será demais reiterar que somos sobretudo um povo pobre - paupérrimo - de técnicos, que ajudem a assegurar maior produtividade aos esforços quase sôbre-humanos que, há tantos séculos, vimos despendendo para constituir o patrimônio nacional .

São variadas, por isto mesmo, nos últimos anos, as transformações por que vem passando o nosso mercado de trabalho, sobretudo o altamente qualificado; e tão complexas e difíceis de caracterizar que não tentaremos fazê-lo nestas poucas linhas e neste local. O técnico de qualquer especialidade tornou-se, porém, avis-rara entre nós e cabe ao Govêrno Federal, mais que a qualquer outro govêrno, criá-lo com desvêlo, ainda que sob o risco de o treinar e adestrar em benefício de emprêsas privadas, sempre disposias a entrar em concorrência pelo trabalho qualificado, mas raramenie inclinadas a favorecer a sua formação. Assume, destarte, o problema do aperfeiçoamento e treinamento do pesscal, direta ou indiretamente ligado à administração pública, uma importância que aos nossos homens responsáveis não é mais dado desconhecer, sob pena de não dotar a economia do país ou a máquina administrativa de condições de eficácia no funcionamento.

O Técnico precisa, no entanto, de ser mais compreendido e bem pago, a fim de acautelar o serviço público ou as emprêsas particulares das imposturas dos pseudo técnicos - às vêzes, estrangeiros... - que the são inculcados, sabe Deus por que portas travessas. E precisa ser melhor utilizado, ao invés de a êle recorrerem para legitimar a posteriori situações embaraçosas ou casos irremovíveis.

Não seria irreverência, em muitos casos, aplicar à nossa administração o que observou o Sr. LyNN SMrth. Quando consideramos os serviços e empreendimentos dos Governos brasileiros federal, estadual ou municipal - embora mais variados e valiosos do que em geral se admite - a conclusão logo se impõe de que só se realizam à custa de uma desordenada e insensata despesa de trabalho e capital. Que deponha a respeito o orçamento federal - essa exemplificação da lei dos rendimentos decrescentes... Assim, uma conclusão rudimentar e óbvia se impõe: convém planejar, organizat, sistematizar, estabelecer métodos e rotinas, a fim de ao menos 
atenuar o esbanjamento. Seria o Técnico de Administração o instrumento por excelência a ser utilizado nessa tarefa racionalizadora. Mas - cabe aqui outra pergunta e esta entre irônica e melancólica - tem sido usado êsse instrumento em tempo hábil e situações apropriadas? Fôrça é reconhecer que não.

A carreira de Técnico de Administração poderá tornar-se, con. tudo, um instrumento precioso para a ação e empreendimentos do Govêrno Federal. Já provou que o é, e em circunstâncias várias, antes de tudo pela autoridade das idéias e dos principios que os seus ocupantes defendem. A despeito de tudo, urge revitalizá-la, confiando-lhe as tarefas que the são inerentes, e fortalecer-1he os quadros mediante uma seleção oportuna e rigorosa. 